\title{
ACETIC ACID AND ETHYL ACETATE IN MADEIRA WINES: EVOLUTION WITH AGEING AND ASSESSMENT OF THE ODOUR REJECTION THRESHOLD
}

\author{
ÁCIDO ACÉTICO E ACETATO DE ETILO EM VINHOS MADEIRA: EVOLUÇÃO COM O \\ ENVELHECIMENTO E AVALIAÇÃO DO LIMIAR DE REJEIÇÃO OLFACTIVA
}

\author{
Andreia Miranda ${ }^{1,2}$, Vanda Pereira ${ }^{1,2}$, Marisela Pontes ${ }^{3}$, Francisco Albuquerque ${ }^{3}$, José C. Marques ${ }^{1,2}$ \\ ${ }^{1}$ Faculty of Exact Sciences and Engineering, University of Madeira, Campus da Penteada, 9020-105, Funchal, Portugal. \\ ${ }^{2}$ Institute of Nanostructures, Nanomodelling and Nanofabrication (I3N), University of Aveiro, 3810-193 Aveiro, Portugal. \\ ${ }^{3}$ Madeira Wine Company, SA, Plataforma 3, Pavilhão T, Zona Franca Industrial, 9200-047 Caniçal, Machico. \\ *corresponding author: Tel.: +351 291705122, e-mail: vpereira@uma.pt
}

(Received 21.12.2016. Accepted 17.02.2017)

SUMMARY

Madeira wine is an internationally recognized fortified wine, characterized by a complex flavour and high longevity. Little is known about the impact of volatile acidity in its features along ageing. Thus, this work studied the evolution of acetic acid and ethyl acetate (volatile acidity main contributors) during the ageing processes used in Madeira wine production, canteiro and estufagem. Wines aged in canteiro for 6 up to 45 years were also evaluated. The odour rejection thresholds (ORT) were assessed in sweet (Malvasia) and dry (Sercial) wines with 5 and 10 years old, by a regular consumer panel and a non-regular consumer panel. The results showed that the formation trend of acetic acid and ethyl acetate is similar in both ageing processes and is favoured by the ageing, mostly in sweet wines. The ORT of ethyl acetate was in average $328 \mathrm{mg} / \mathrm{L}$ for both panels, while for acetic acid ranged between 1.96 and $5.72 \mathrm{~g} / \mathrm{L}$, depending on the evaluation panel and also on the age and sweetness degree of the Madeira wine. The ORT values expressed in volatile acidity ranged between 1.4 and $3.5 \mathrm{~g} / \mathrm{L}$, which are higher than the legal limits. The study pointed out that the olfactory perception of acetic acid and ethyl acetate in Madeira wines depends on their age and sweetness degree.

\section{RESUMO}

O vinho Madeira é um vinho fortificado reconhecido internacionalmente, caracterizado por um sabor e aroma complexo e elevada longevidade. Pouco se sabe sobre o impacto da acidez volátil nas suas características ao longo do envelhecimento. Assim, este trabalho estudou a evolução do ácido acético e do acetato de etilo (principais contribuintes da acidez volátil) durante os processos de envelhecimento usados na produção de vinho Madeira, canteiro e estufagem. Também foram avaliados vinhos envelhecidos em canteiro por 6 até 45 anos. Os limiares de rejeição olfativa (ORT) foram determinados em vinhos doces (Malvasia) e secos (Sercial) com 5 e 10 anos de idade, por um painel de consumidores regulares e um painel de consumidores não regulares. Os resultados mostraram que a tendência de formação do ácido acético e do acetato de etilo é similar em ambos os processos de envelhecimento e é favorecida com a idade, sobretudo nos vinhos doces. O ORT do acetato de etilo foi em média $328 \mathrm{mg} / \mathrm{L}$ para ambos os painéis, enquanto para o ácido acético variou entre 1,96 e 5,72 g/L dependendo do painel de avaliação e também da idade e do grau de doçura do vinho Madeira. Os valores de ORT, expresso em acidez volátil, variaram entre 1,4 e 3,5 g/L, que são superiores aos limites legais. O estudo revela que a perceção olfativa do ácido acético e do acetato em vinhos Madeira depende da sua idade e grau de doçura.

Key words: wine ageing, volatile acidity, sensorial analysis, acetic acid, ethyl acetate.

Palavras-chave: envelhecimento do vinho, acidez volátil, análise sensorial, ácido acético, acetato de etilo.

\section{INTRODUCTION}

Madeira fortified wine, with an alcoholic content between 17 and $22 \%(\mathrm{v} / \mathrm{v})$, is essentially served as an aperitif or digestive. These wines are produced in different styles, with the following sweetness degrees: dry (total sugars: 49.1-64.8 g/L), medium-dry (64.8$80.4 \mathrm{~g} / \mathrm{L})$, medium-sweet $(80.4-96.1 \mathrm{~g} / \mathrm{L})$ and sweet wines (>96.1 g/L) (IVBAM, 2017). The finest Madeiras are usually aged exclusively by canteiro, which consists on ageing the wine in oak casks at wine cellar lofts (temperature usually ranging 
between 15 and $31{ }^{\circ} \mathrm{C}$ ) for at least 3 years before being commercialized, while the majority is firstly submitted to a thermal processing, for at least 3 months, typically at about $45{ }^{\circ} \mathrm{C}$ (estufagem process) and then undergo to oak casks (Pereira et al., 2013). Besides their high longevity, these fortified wines are known to exhibit an intense and complex flavour, acquired during their peculiar ageing process, and a high acidity well balanced with their sweetness.

Volatile acidity (VA) is one of the most important characteristics of wines, contributing directly and indirectly for their quality. The VA represents the measure of all the steam distillable volatile acids present in wines (Jackson, 2008). Acetic acid is the major compound $(90 \%)$ and, for that reason, VA is usually expressed in terms of this acid. Although other minor compounds (such as formic, lactic, butyric and propionic acids) are also included, they rarely occur above their odour threshold levels. It is not possible to produce wine without VA, since acetic acid can be primarily formed during the fermentation step by yeasts and bacterial metabolism, such as lactic acid bacteria (LAB) and acetic acid bacteria (AAB), and also by the chemical hydrolysis of hemicelluloses during wine maturation in oak casks (Jackson, 2008). $\mathrm{AAB}$ can influence the wine quality essentially by grape contamination, growth during alcoholic fermentation and storage in wine cellars. AAB (namely Acetobacter) may be present in old wooden barrels and tend to grow in oxygenated environments, producing acetic acid (Joyeux et al., 1984). Nevertheless, in fortified wines most of Acetobacter activity is inhibited due the elevated alcohol content (Schaechter, 2009). Wildenradt and Singleton (1974) studies showed that during oxidative wine maturation occurs the production of aldehydes from ethanol and that ethanol oxidation leads to the formation of acetic acid. High levels of VA may be an indicator of spoiled wines and, for that reason, Lambrechts and Pretorius (2000) suggest that the VA amount in wines usually lies between 500 to $1000 \mathrm{mg} / \mathrm{L}$. VA levels are usually between 0.25 to $0.50 \mathrm{~g} / \mathrm{L}$, however, depending on the fermentation conditions (such as botrytized musts) the values can reach $1.8 \mathrm{~g} / \mathrm{L}$ or higher (Bely et al., 2003). Moreover, the VA levels increase during the ageing of wine in barrels (between 0.06 to $0.12 \mathrm{~g} / \mathrm{L}$ after one year in barrels), due to the formation of acetic acid from the degradation of the hemicelluloses and phenolic compounds derived from wood barrels (Zoecklein, 2012).

The recognition of VA in wines, namely the "acetic nose", is not exclusively the result of the acetic acid levels, but severally depends on the acetic acid and ethyl acetate ratio (Zoecklein, 2012). The concentration of both compounds in wine depends severally on the yeast strain (Erasmus et al., 2004; Vilela-Moura et al., 2010), since that, as acetic acid, ethyl acetate can also be formed by the action of yeasts during fermentation, and by the action of $\mathrm{AAB}$ during ageing (Nogueira and Nascimento, 1999).The presence of both compounds below perceptible levels can enhance the fruitiness flavour and add complexity to wine, while above it can be considered undesired and may evidence microbiological problems (Cliff and Pickering, 2006). The odour perception of the acetic acid and ethyl acetate can differ from wine to wine, depending on the grape variety (red or white) used in its production (Corison et al., 1979; Zoecklein, 2012).

There are several methodologies for the evaluation of sensory thresholds: those involving the detection threshold defined as the minimum value of a sensorial stimulus needed to give rise to a sensation, namely odor detection threshold (ODT) and taste detection threshold (TDT), usually using a triangular tests; and those involving the consumer perception, the consumer rejection threshold (CRT), which usually involves a paired comparison tests to evaluate the point at which wine consumer would begin to reject a wine (Teixeira et al., 2006; Campo et al., 2012). Several authors have been adopting this strategy to assess the consumer evaluation since this information is quite important for the wine industry. Prescott et al. (2005) developed this new concept, assessing the CRT of 2,4,6-trichoroanisole (TCA) in white wines. Later, others studies were performed in order to evaluate the CRT of eucalyptol in Australian red wines (Saliba et al., 2009) and ethyl phenylacetate and phenylacetic acid in Spanish red wine (Campo et al., 2012). However, Lima Filho et al. (2015) proposed other approach for the sensory threshold evaluation of a product.

Maximum legal limits imposed for VA are different in each country and depend on the type of wine and even on the sweetness degree (Jacobson, 2006; Goode and Harrop, 2011). For instance, according to the latest revision (Portaria $n^{\circ} 302 / 2011$ ), the volatile acidity maximum legal limit (expressed in terms of acetic acid) in Madeira wine is: $1.2 \mathrm{~g} / \mathrm{L}$ for wines with or less than 10 years-old (yo); $1.5 \mathrm{~g} / \mathrm{L}$ for wines between 10 to 20 yo and $1.8 \mathrm{~g} / \mathrm{L}$ for wines with or greater than 20 yo. Legal limits are often contested, since wine characteristics can, in certain way, mask its perception. For example, Cliff and Pickering (2006) studied the ice wine of Canada and demonstrate that the odour rejection threshold (ORT) of acetic acid was $3.19 \mathrm{~g} / \mathrm{L}$, even though the volatile acidity legal limit in force was $2.1 \mathrm{~g} / \mathrm{L}$. The ORT of ethyl acetate found for these wines was $198 \mathrm{mg} / \mathrm{L}$. On the other hand, Corison et al. (1979) found higher 
levels of acetic acid ORT for white wines (1190 $\mathrm{mg} / \mathrm{L})$ than for red wines $(900 \mathrm{mg} / \mathrm{L})$. Contrarily, the ethyl acetate ORT presented an opposite result, being $60 \mathrm{mg} / \mathrm{L}$ in white wines and $115 \mathrm{mg} / \mathrm{L}$ in red wines. Also, Lambrechts and Pretorius (2000) reviewed the importance of yeast on the wine aroma and reposted that the acetic acid perception values can varied between 0.1 to $0.4 \mathrm{~g} / \mathrm{L}$.

Studies performed by Pereira et al. (2014) revealed an increase of the acetic acid levels of wines submitted to estufagem for a 3-month period, ranging between 55 to $156 \mathrm{mg} / \mathrm{L}$. Also, Câmara et al. (2006) showed that the ethyl acetate levels increase during aging to values ranging between 24 to $264 \mathrm{mg} / \mathrm{L}$, depending on the grape variety. Despite the scientific studies undertaken in the last decades on Madeira wines, the impact of acetic acid and ethyl acetate on the odour perception is still little known. Therefore, the current study appraised to follow the evolution of acetic acid and ethyl acetate during the ageing processes commonly used in Madeira wine production (canteiro vs. estufagem) for the first time. Wood-aged Madeira wines with different ages (5 and 10 yo) and sweetness degrees (dry and sweet wines) were also studied. Additionally, another aim was to estimate the ORT of acetic acid and ethyl acetate, at different ages and sweetness degrees, to determine the point at which Madeira wine consumers would begin to reject it due to sensory perception of vinegar-like odours.

\section{MATERIAL AND METHODS}

\section{Samples}

Two Vitis vinifera L. white varieties, traditionally used to produce the finest dry and sweet Madeiras, Sercial and Malvasia, respectively, were used. Three sample groups were evaluated:

Young Madeira wines aged by canteiro and estufagem

Sercial and Malvasia wines were prepared from about $1000 \mathrm{~kg}$ of grapes, harvested in 2011 in Madeira Island. The wines were produced according to the winemaking practices of a local Madeira wine producer, in separated stainless steel tanks. $\mathrm{A} \mathrm{SO}_{2}$ solution $(15 \% \mathrm{v} / \mathrm{v})$ was added to the initial grape juice to obtain a sulphur dioxide concentration of about 60 $\mathrm{mg} / \mathrm{L}$. The grape juice together with skins followed 24 hours of maceration. The alcoholic fermentation (without grape solids) was conducted under controlled temperature $\left(20 \pm 3{ }^{\circ} \mathrm{C}\right)$, without adding any commercial yeasts. When the desired must density was attained, the fermentation process was stopped by the addition of natural wine spirit (containing 95\% (v/v) of ethanol), producing a dry (Sercial) and a sweet (Malvasia) wine. Then, the wines were submitted to clarification before ageing in new medium toasted American oak casks. Different vinification stages were evaluated: initial must (M0); must after maceration (MAM); must before fortification (MBF); wine after fortification (WAF) and wine after post-fermentation treatments (WAT). Three wine replicates were collected at the different stages.

Each wine was divided in two fractions of about 200 L: one was aged exclusively by canteiro (wines were directly placed into wood casks in wine cellar lofts) and other was previously submitted to estufagem (45 ${ }^{\circ} \mathrm{C}$ during 120 days) and then followed ageing in wood casks. Three wine replicates were sampled in the following stages: W0, W30, W60, W90, W120, W180, W360 and W540. The stage W0 corresponds to the wine before starting the ageing process, while the others stages indicate how many days the wine aged.

\section{Old Madeira wines aged by canteiro}

A set of 16 Madeira wine samples from the same wine company (commercially unavailable), aged in reused oak casks between 6 to 45 years and made from Sercial (7) and Malvasia (9) grapes, was selected.

\section{Commercial wines with 5 and 10 yo}

Commercial wines were selected for the estimation of the ORT values: two from Sercial, dry wines with 5 and 10 yo, and also two from Malvasia, sweet wines with 5 and 10 yo.

\section{Acetic acid determination}

An IEC-HPLC-DAD methodology was developed for the determination of acetic acid using the Alliance (Waters Corporation, Milford, MA, USA) 2695 separation module equipped with the 2996 photodiode array detector (detection at $210 \mathrm{~nm}$ ). The configuration and the data processing were driven by the Empower Pro software. An Agilent Hi-Plex H $(300 \times 7.7 \mathrm{~mm} ; 8 \mu \mathrm{m})$ column (Santa Clara, CA, USA) with a sulphuric acid $(0.0025 \mathrm{M})$ isocratic elution was used for the chromatographic separation. The flow rate was set to $0.6 \mathrm{~mL} / \mathrm{min}$, the column thermostated at $65^{\circ} \mathrm{C}$ and the injection volume was $10 \mu \mathrm{L}$. The three wine replicates were analysed twice. All samples were filtered using $0.45 \mu \mathrm{m}$ CHROMAFIL $® X$ tra syringe filters (Düren, Germany). Acetic acid was identified based on the retention time and by spiking the samples with the pure standard compound (99.7\%, Panreac Química S.A., Barcelona, Spain). The calibration curve ranged 
between $0.05-5 \mathrm{~g} / \mathrm{L}$, with $y=464 x+1140$ ( $y$, peak area; $x$, concentration of acetic acid), $\mathrm{R}^{2}=0.999$ and LOQ (limit of quantification) of $0.08 \mathrm{~g} / \mathrm{L}$, estimated by LOQ $=10 \sigma / b$, with $\sigma$ as the $y$-intercept standard deviation and $b$ the slope of the linear regression. The method precision was assessed by repeatability (intraday precision of 10-successive analysis) and reproducibility (interday precision, repeating three analyses on three different days) assays showing RSD (relative standard deviation) values lower than $4 \%$. The method accuracy was assessed spiking wine samples with known amounts of acetic acid standard at two representative concentration levels. The recovery was in average $102 \%$.

\section{Ethyl acetate determination}

A $500 \mathrm{mg} / \mathrm{L}$ 3-octanol (97\%, Acros Organics, Geel, Belgium) solution prepared in synthetic wine $(6 \mathrm{~g} / \mathrm{L}$ in tartaric acid, $18 \%$ of ethanol and $\mathrm{pH}$ adjusted to 3.50 with $1 \mathrm{M} \mathrm{NaOH}$ ) was prepared to spike the wine samples, to be used as internal standard (IS). Then, 10 $\mu \mathrm{L}$ of the previous solution were added to $20 \mathrm{~mL}$ of each sample, before diluting $5 \mathrm{~mL}$ into $5 \mathrm{~mL}$ of ultrapure water in a headspace vial containing $3 \mathrm{~g}$ of $\mathrm{NaCl}$ (99.5\%, Panreac Química S.A, Spain). Ethyl acetate was extracted by HS-SPME and analysed by GC-MS. The extraction was performed by exposing the Divinylbenzene/Carboxen/Polydimethylsiloxan

(DVB/CAR/PDMS, bipolar adsorbent) $50 \mu \mathrm{m} / 30 \mu \mathrm{m}$ SPME fiber, from Supelco (Bellefonte, PA, USA), into the vial for $30 \mathrm{~min}$ at $60{ }^{\circ} \mathrm{C}$, keeping the sample under continuous stirring, after a 5-min incubation. The compounds were desorbed for $5 \mathrm{~min}$ at $240{ }^{\circ} \mathrm{C}$ into the $\mathrm{GC}$ inlet. The chromatographer was comprised by the TriPlus autosampler (SPME mode) and the ISQ single quadrupole mass spectrometer (electronic impact ionization mode) from Thermo Scientific (Hudson, NH, USA). The column was a DB-WAXetr, $30 \mathrm{~m} \times 0.250 \mathrm{~mm}$ and $0.50 \mu \mathrm{m}$ of film thickness (Agilent J\&W, Folsom, CA, USA). The carrier gas was helium at $1 \mathrm{~mL} / \mathrm{min}$. The transfer line and ion source temperatures were both kept at $240{ }^{\circ} \mathrm{C}$. The oven temperature program started at $40{ }^{\circ} \mathrm{C}$ for 5 min then increased up to $230{ }^{\circ} \mathrm{C}$ at $40{ }^{\circ} \mathrm{C} / \mathrm{min}$ and finally kept at $230{ }^{\circ} \mathrm{C}$ for $15 \mathrm{~min}$. The quantification was done using the fragment ion $\mathrm{m} / \mathrm{z} 61$ for ethyl acetate and $\mathrm{m} / \mathrm{z} 101$ for the IS. The validation parameters were obtained as previously described. Particularly, ethyl acetate (99.98\%, Fisher Scientific, Loughborough, UK) standard solutions were prepared in the range $25-500 \mathrm{mg} / \mathrm{L}$, obtaining the calibration curve $y=0.0478 x+0.165$ (y, relative area, which is the ratio between the peak areas of ethyl acetate and 3-octanol; $x$, concentration of ethyl acetate), $\mathrm{R}^{2}=$ 0.999 and LOQ of $10.83 \mathrm{mg} / \mathrm{L}$. The precision RSD values were lower than $5 \%$ and the recovery was in average $95 \%$. Three wine replicates were analysed twice.

\section{Volatile acidity determination}

VA was obtained using Bacchus 3 MultiSpec analyser, fitted with an iD1 transmission accessory and patent from Tecnología Difusión Ibérica, S.L (Barcelona, Spain). The equipment includes a rapidscanning infrared Fourier-transform spectrophotometer, Nicolet iS5 from Thermo Scientific (spectral zone range between $7800-350$ $\mathrm{cm}^{-1}$ ), with $\mathrm{CaF}_{2}$ windows, a Czerny-Turner UV-Vis spectrophotometer $(250-600 \mathrm{~nm})$ fitted with $0.2 \mathrm{~mm}$ flow cells and an autosampler with previous thermostatization of the samples by peltier effect at $27{ }^{\circ} \mathrm{C}$. The adjustment of the standard calibration provided by the Bacchus Analysis software was performed, recording a wide spectral zone that covers UV-Vis-IR (250-3000 $\mathrm{nm}$ ) and using VA reference values of 259 Madeira wines, which were determined according to the OIV-MA-AS313-02 method from the International Organisation of Vine and Wine (OIV, 2015). The calibration equation was $y=1.1 x$ 0.46 with $\mathrm{R}^{2}=0.970$. The samples were filtered using $0.45 \mu \mathrm{m}$ CHROMAFIL $®$ Xtra syringe filters before analysis.

\section{ORT assessment}

The ORT assessment of acetic acid and ethyl acetate was performed based on the studies of Prescott et al. (2005), evaluating the consumer perspective about the rejection threshold. Considering that Madeira wine consumption is not so usual among consumers and it is usually served as aperitif or digestive, the nonhomogeneity of consumers was then considered. In order to evaluate if there were important differences between tasters, two panels were recruited: panel 1 (regular wine consumer's), composed by 12 wine professional tasters ( 6 females and 6 males, aged between 25 and 58 yo) and panel 2 (non-regular wine consumer's) formed by 23 staff and students from the University of Madeira (10 males and 13 females, aged between 23 and 35 yo). In order to obtain more reliable results a basic training was performed based on paired comparison and ranking (intensity) tests.

Acetic acid and ethyl acetate standards were added to the base wine ( 5 and 10 yo Sercial and Malvasia), which have the intrinsic amounts described in Table I. For the ORT of acetic acid, it was used the following concentrations: $0.3,0.6,1,2$ and $2.5 \mathrm{~g} / \mathrm{L}$ for the panel 1 and $1,2,3,5$ and $8 \mathrm{~g} / \mathrm{L}$ for the panel 2. Ethyl acetate ORT's assessments were carried out adding $50,100,200,300$ and $400 \mathrm{mg} / \mathrm{L}$ for both panels. These ranges were selected on the basis of a preliminary study, using a small group of tasters, 


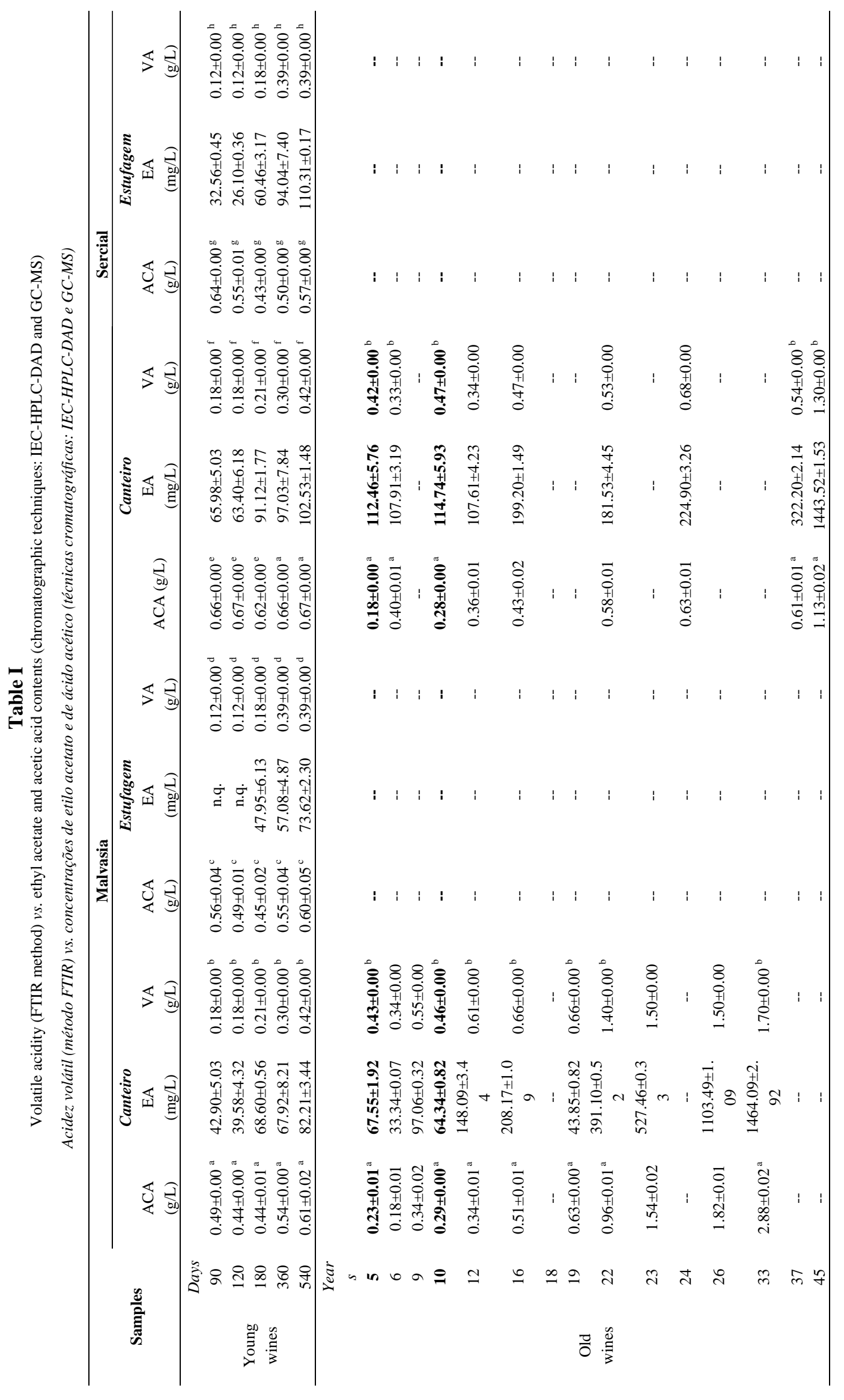


based on paired comparison tests in order to define the concentration from which the tasters show sensitivity for the stimulus.

The ORT of acetic acid and ethyl acetate were measured using a replicate series of five groups with two samples each, containing $30 \mathrm{~mL}$ of wine solution: base and spiked wine. Madeira wines were served at $20 \pm 2^{\circ} \mathrm{C}$. The groups were arranged in increasing order of concentration and the glasses were covered with petri-dishes. The presentation order of control wine with each pair was randomized. Samples were assessed at room temperature only by sniffing. An aqueous solution of each standard was provided, so that the tasters become familiarised with its odour and then it was asked to indicate the preferred sample. The criteria used for the rejection (percent of assessors that have chosen the sample without the standard) were based on the binomial distribution tables for paired comparison tests with 5\% of significance for $N$ assessors, according to the ISO Standard 5495:2005. A free-odour room design for sensorial tests was used. The absence of odours was ensured to avoid their influence with the wine tasting. Each taster performed the sensorial evaluation individually.

\section{Data analysis}

Significant differences were evaluated by the analysis of variance (One-way ANOVA, Holm-Sidak method) using the statistical software SigmaPlot 12.0.

\section{RESULTS AND DISCUSSION}

The acetic acid evolution was firstly assessed at several stages during Sercial and Malvasia vinification process (Figure 1) and significant differences $(\mathrm{p}<0.05)$ were found, especially during the fermentation step (MAM to MBF), which was expected, since acetic acid levels are known to increase significantly during the alcoholic fermentation due to yeast activity (Remize et al., 2000). Sercial revealed higher amounts (626 mg/L) than Malvasia (516 mg/L) due to its longer fermentation and prolonged yeast's action. During maceration (M0 to MAM), it was verified a slight increase of acetic acid level in Sercial wine, up to 152 $\mathrm{mg} / \mathrm{L}$, which might indicate the presence of some AAB in grapes (Drysdale and Fleet, 1988). In regard to the fortification step (MBF -WAF) important changes were only observed for Malvasia wine, due to the higher addiction of wine spirit usually performed in sweet wines (lower alcoholic content). No significant difference was found when the postfermentation treatments (WAF-WAT) were applied to both wines.

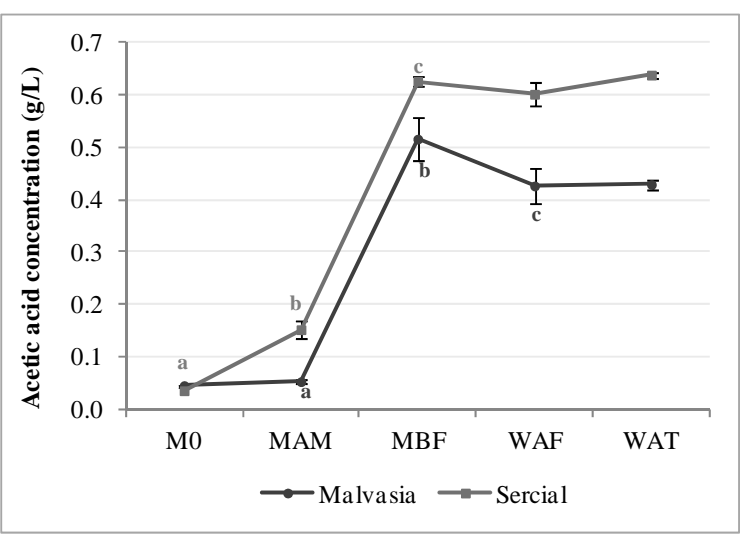

Figure 1. Acetic acid evolution during the Madeira wine vinification process: initial must (M0); must after maceration (MAM); must before fortification (MBF); wine after fortification (WAF) and wine after post-fermentation treatments (WAT). Different letters in each line means that significant differences $(\mathrm{p}<0.05)$ were found.

Evolução do ácido acético durante o processo de vinificação do vinho Madeira: mosto inicial (M0); mosto após maceração (MAM); mosto antes da fortificação (MBF); vinho após a fortificação (WAF) e vinho após os tratamentos pós-fermentativos (WAT). Letras diferentes em cada linha significam que foram encontradas diferenças significativas $(p<0,05)$.

Figure 2 (a,c) shows that both ageing processes (canteiro and estufagem) promoted similar levels of acetic acid, since that no significant differences were found ( $>0.05)$. As previously reported by Pereira (2011), estufagem does not seem to promote a noticeable increase on the acetic acid amount, if temperature is well controlled $\left(45{ }^{\circ} \mathrm{C}\right.$ during 4 months). Similar to Pereira et al. (2014), it was also observed that the ageing process promoted the development of acetic acid, especially in sweet wine, increasing up to $28 \%$. A notable increase was observed between 180 to 360 days of aging for both wines (Figure 2 a,c). Canteiro revealed greater concentrations than estufagem (significant differences were found with $\mathrm{p}<0.05$ ), however both ageing processes tend to approach over time. Figure 2 (b,d) shows that ethyl acetate increases during both ageing processes, especially in Sercial wines (up to 111 mg/L) after 120 days of ageing. Câmara et al. (2006) also evidence an increase in the ethyl acetate concentration during Madeira wines ageing. In this type of ageing, oxygen is present and it is known to react with the acetic acid to form ethyl acetate (Fugelsang and Edwards, 2007). Indeed, the wines that were submitted to estufagem revealed an important increase (significant differences were found with $\mathrm{p}<0.05$ ), in their ethyl acetate levels, after being transferred to wood cask (120 days). 


\section{Malvasia}
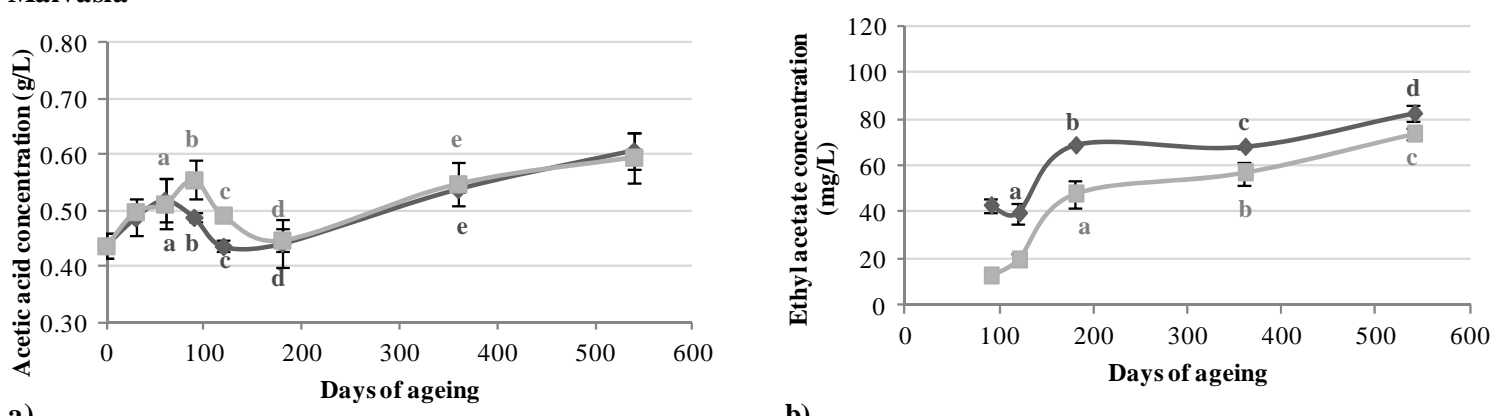

a)

b)
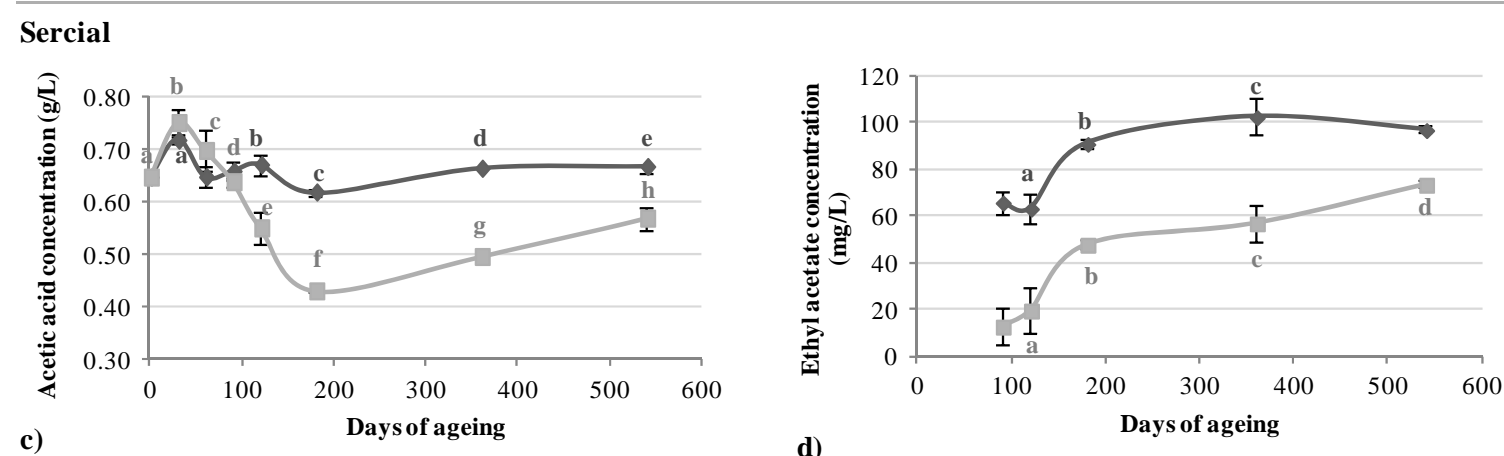

d)

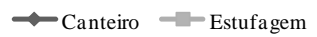

Figure 2. Evolution of acetic acid and ethyl acetate in young Malvasia and Sercial wines during both ageing processes (canteiro vs. estufagem) up to 540 days of ageing. Different letters in each line means that significant differences $(\mathrm{p}<0.05)$ were found.

Evolução do ácido acético e acetato de etilo em vinhos novos, Malvasia e Sercial, durante ambos os processos de envelhecimento (canteiro vs. estufagem) até 540 dias de envelhecimento. Letras diferentes em cada linha significam que foram encontradas diferenças significativas ( $p<0,05$ ).

Madeira wines that undergone wood ageing for several years (from 6 to 45 years) revealed an exponential increase of acetic acid and ethyl acetate levels (Figure 3), being more accentuated in sweet wines. It can also be highlighted that a correlation was found between both compounds (Malvasia: $\mathrm{R}^{2}=0.965$; Sercial: $\left.\mathrm{R}^{2}=0.808\right)$. Therefore, the increase in the ethyl acetate amount depends directly on the acetic acid concentration, as was previously found by other studies (Câmara et al., 2006; Rudnitskaya et al., 2010; Pereira, 2011). During wood ageing, the increase of acetic acid is usually related to the production of aldehydes from ethanol followed by ethanol oxidation (Wildenradt and Singleton, 1974). However, it also seems to depend severely on the sugar content.

Figure 3 demonstrates that older wines present higher acetic acid values than table wines $(0.2$ to $0.4 \mathrm{~g} / \mathrm{L})$ (Delfini and Formica, 2001; Goode and Harrop, 2011), however it is not noticeable in the sensory test.
Therefore, it becomes important to assess the ORT values of acetic acid and ethyl acetate in these wines.

Two different panels evaluated the ORT in wines with different ages and sweetness degrees. The ORT indicates the concentration at which there was a statistically significant preference for the un-spiked sample. As the concentration of acetic acid and ethyl acetate increases, the vinegar-like odour become more noticeable and more participants choose the control sample. Acetic acid intrinsic amounts were taken into account in the total concentration (Table I). Figure 4 shows that lower ORT values are obtained with the panel 1 (ranging from 1.96 to $2.60 \mathrm{~g} / \mathrm{L}$ ). The panel 2 revealed ORT values between $4.41-5.72 \mathrm{~g} / \mathrm{L}$. These results clearly reveal that the perception of the vinegar sensation is influenced by the consumer's experience, in regard to Madeira wine consumption. Thus, to conciliate the wine market demands and the wine quality assurance, the panel 1 evaluation should be considered. 


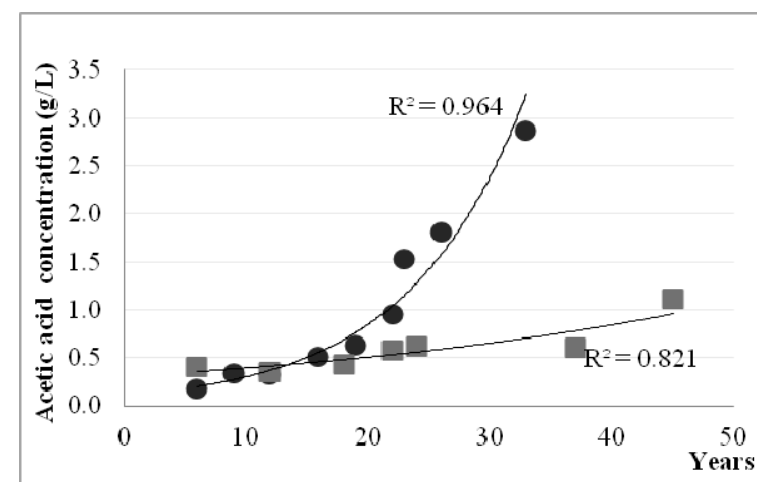

a)

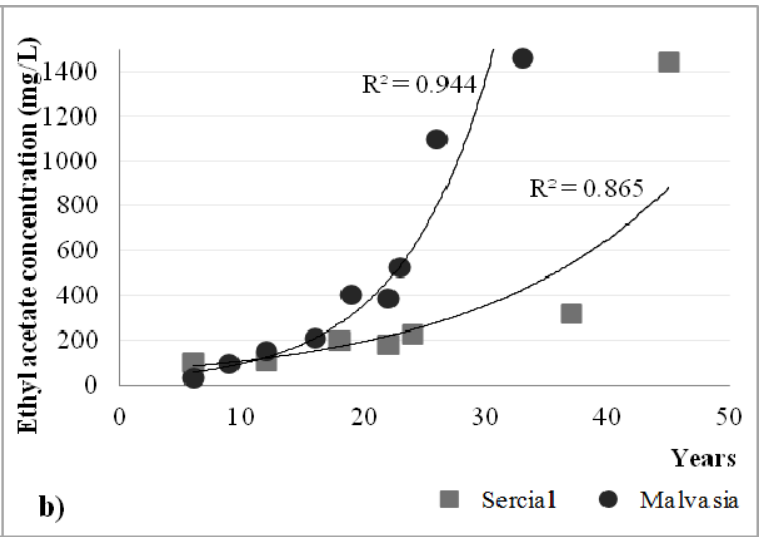

b)

Figure 3. Evolution of acetic acid (a) and ethyl acetate (b) in the Malvasia and Sercial wines under wood ageing (canteiro).

Evolução do ácido acético (a) e do acetato de etilo (b) nos vinhos Malvasia e Sercial em envelhecimento em madeira (canteiro).
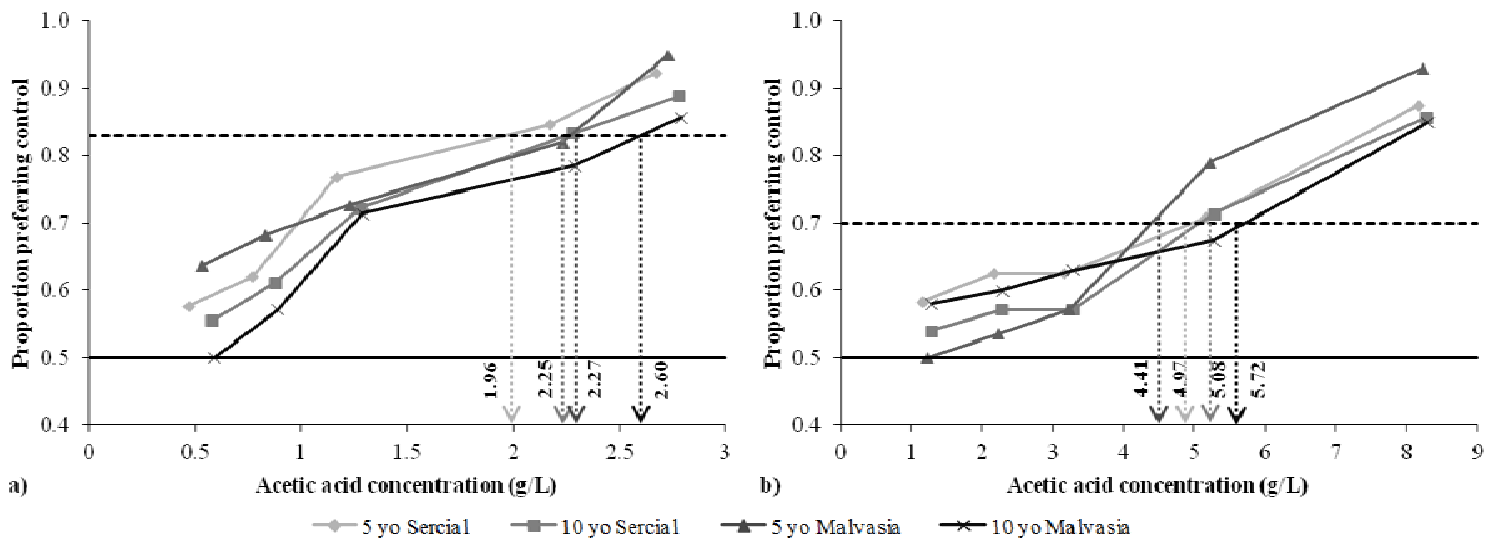

Figure 4. Proportion of the participants that preferred the control wine for each acetic acid level. The line 0.5 represents the results obtained by random response. The ORT was calculated using $5 \%$ significance criterion for paired comparison tests represented by the dotted line (0.83) with $\mathrm{n}=12$ for panel 1 (a) and (0.70) with $\mathrm{n}=23$ for the panel 2 (b).

Proporção de participantes que preferiram o vinho controlo para cada nível de ácido acético. A linha 0.5 representa os resultados obtidos pela resposta aleatória. O ORT foi calculado usando o critério de 5\% de confiança para os testes de emparelhamento representados pela linha a tracejado (0.83) com $n=12$ para o painel 1 (a) e (0.70) com $n=23$ para o painel 2 (b).

According to Table I, generally, acetic acid measurements were quite different from those found for VA (significant difference, with $\mathrm{p}<0.05$, were found in the majority of the samples). Literature refers that both are very closed correlated in juice and young wines (Jacobson, 2006). In this case, Madeira young wines presented acetic acid levels 2.5-fold higher than VA levels, while in old wines this difference becomes not so evident. Considering this issue, the acetic acid ORT values found by both panels were expressed in VA by extrapolation, in order to determine if the rejection perception was within the legal limits. The linear regressions were obtained plotting the concentration of acetic acid present in wines (Sercial: $y=0.528 x+0.486$, $\mathrm{R}^{2}=0.995$ and Malvasia: $y=0.505 x+0.380$, $\mathrm{R}^{2}=0.999$ ) after the different spikes (used in the sensorial evaluations) against the VA response. In this sense, VA values varied between $1.4-1.9 \mathrm{~g} / \mathrm{L}$ for the panel 1 and $2.8-3.5 \mathrm{~g} / \mathrm{L}$ for the panel 2. It was verified that even the lower ORT value obtained ( 5 yo Sercial in the panel 1) is above the limit currently in force for the volatile acidity of 5 and 10 yo Madeira wines (Portaria $n^{\circ}$ 302/2011). Additionally, the results 
from panel 1 revealed that the ORT of acetic acid seems to depend on the sweetness and age of wine. Both panels demonstrated higher ORT for Malvasia wines. In fact, higher levels of sugar and ethanol are known to mask the VA perception (Corison et al., 1979; Cliff and Pickering, 2006). Ethyl acetate intrinsic levels were taken into account in the total concentration (Table I). Figure 5 shows the ORT values of ethyl acetate found by both panels, which were quite similar, in average $328 \mathrm{mg} / \mathrm{L}$, indicating that the perception of ethyl acetate scent did not depend on consumer experience, as verified in the case of acetic acid. Notwithstanding, it seems reasonable that the panel 1 evaluation ensure the wine quality standards. Thus, VA values lower than $1.4 \mathrm{~g} / \mathrm{L}$ make sure that vinegar-like odours are not perceptible, even by expert consumers. The results indicate that ethyl acetate ORT also depends on the wine style and age: the higher values were obtained for the oldest dry wines. The characteristic acidity of Sercial can probably mask the ethyl acetate perception.
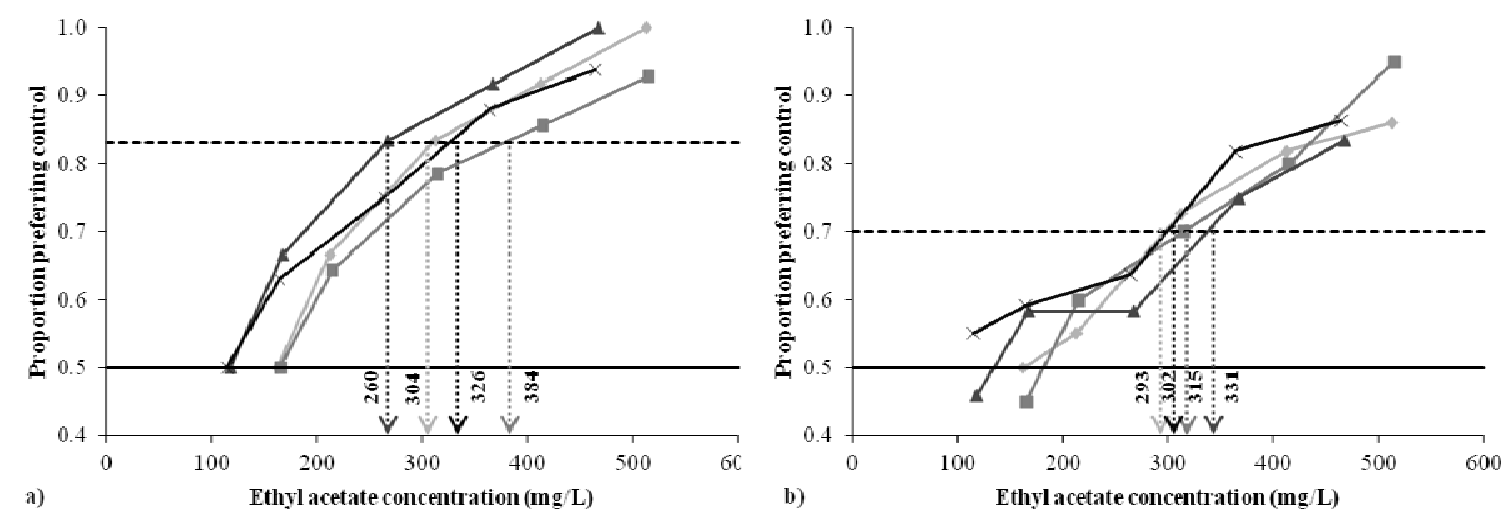

Figure 5. Proportion of the participants that preferred the control wine for each ethyl acetate level. The ORT was calculated using p=0.05 for paired comparison tests with $n=12$ for panel 1 (a) and $n=23$ for the panel 2 (b).

Proporção de participantes que preferiram o vinho controlo para cada nível de acetato de etilo. ORT foi calculado usando $p=0,05$ para os testes de emparelhamento com $n=12$ para o painel 1 (a) e $n=23$ para o painel 2 (b).

The analysis also showed that most old Madeiras (Figure 3) did not surpassed the lower ORT value of acetic acid (1.96 g/L), except the 33 yo Malvasia that, even so, has its volatile acidity $(1.7 \mathrm{~g} / \mathrm{L})$ within the limits legally established $(1.8 \mathrm{~g} / \mathrm{L})$. This wine might not reveal the perception of acetic acid considering that it is expected that the ORT values of 20 yo Madeira wines might be higher than those found for 5 and 10 yo. Indeed, despite the exponential increase of volatile acidity during wood ageing, the Madeira wine quality might not be affected, once its perception seems to depend on the wine age. During ageing in oak casks, there are wood-derived substances (namely ethyl esters) that contribute to the enrichment of the aromatic complexity and the extraction of these substances depends on the quantity of compounds that are potentially extractable, the wine composition and also on the time that wine maturates in wood casks (Garde-Cerdán et al., 2004; Garde-Cerdán and Ancín-Azpilicueta, 2006). So, long ageing periods favour the wine complexity, and consequently the acetic acid perception might be masked.

Regarding ethyl acetate, the ORT were in average 3fold higher than the values found for 10 yo Madeira wines. Older wines (> 20 yo) presented higher ethyl acetate levels ( $>$ ORT found for 10 yo Madeiras). However, taking into consideration that the threshold levels of this ester vary according to the type, intensity of the wine flavour, sugars and ethanol levels (Corison et al., 1979; Cliff and Pickering, 2006), it is expected that the amount found in these wines may not have a negative impact on the aroma.

\section{CONCLUSIONS}

The current study reveals that young Madeira wines have acetic acid contents slight above the contents usually found in new dry table wines $(<400 \mathrm{mg} / \mathrm{L})$ but less than $700 \mathrm{mg} / \mathrm{L}$. It was also found that the levels of acetic acid and ethyl acetate increase during 
the wood ageing of Madeira wines and greatly depends on the sweetness degree. It can also be concluded that the estufagem does not have a great contribution in their formation. The formation of ethyl acetate derives from acetic acid oxidation, since a correlation was found between both compounds during wood ageing. In turn, the ORT of both compounds seems to depend on the Madeira wine age, being higher in older wines. Also, the sweetness degree seems to have a great impact in the ORT values: sweet wines presented higher ORT values for acetic acid and lower for ethyl acetate (considering the evaluation of regular consumers). Therefore, the consumer's odour rejection threshold of acetic acid and ethyl acetate increase with the age and sweetness

\section{REFERENCES}

Bely M., Rinaldi A., Dubourdieu D., 2003. Influence of assimilable nitrogen on volatile acidity production by Saccharomyces cerevisiae during high sugar fermentation. J. of Biosci. Bioeng., 96, 507-512.

Câmara J.S., Alves M.A., Marques J.C., 2006. Changes in volatile composition of Madeira wines during their oxidative ageing. Anal. Chim. Acta, 563, 188-197.

Campo E., Saenz-Navajas M.P., Cacho J., Ferreira V., 2012. Consumer rejection threshold of ethyl phenylacetate and phenylacetic acid, compounds responsible for the sweet-like off odour in wines made from sour rotten grapes. Aust. J. Grape Wine Res., 18, 280-286.

Cliff M.A., Pickering G.J., 2006. Determination of odour detection thresholds for acetic acid and ethyl acetate in ice wine. J. Wine Res., 17, 45-52.

Corison C.A., Ough C.S., Berg H.W., Nelson K.E., 1979. Must acetic acid and ethyl acetate as mold and rot indicators in grapes. Am. J. Enol. Vitic., 30, 130-134.

Delfini C., Formica J.V., 2001. Wine microbiology: Science and technology. 339 p. CRC Press, Italy.

Drysdale G.S., Fleet G.H., 1988. Acetic acid bacteria in winemaking: A review. Am. J. Enol. Vitic., 39, 143-154.

Erasmus D.J., Cliff M., Vuuren H.J., 2004. Impact of yeast strain on the production of acetic acid, glycerol, and the sensory attributes of icewine. Am. J. Enol. Vitic., 55, 371-378.

Fugelsang K.C., Edwards C.G., 2007. Wine microbiology: Practical applications and procedures. 91-92 p. Springer, USA.

Garde-Cerdán T., Ancín-Azpilicueta C., 2006. Review of quality factors on wine ageing in oak barrels. Trends Food Sci. Technol., 17, 438-447.

Garde-Cerdán T., Goñi D.T., Azpilicueta C.A., 2004. Accumulation of volatile compounds during ageing of two red wines with different composition. J. Food Eng., 65, 349-356.

Goode J., Harrop S., 2011. Authentic wine: Toward natural and sustainable winemaking. 215-216 p. University of California Press, USA. degree of Madeira wine, since the complexity enhances and masks their perception.

\section{ACKNOWLEDGMENTS}

The current study was supported by FEDER, Intervir+ program under the project IMPACT II (MADFDR-01-0190-FEDER-000010). A. Miranda and V. Pereira acknowledge the Agência Regional para o Desenvolvimento da Investigação Tecnologia e Inovação (ARDITI) under the Project M1420 - 095369-FSE-000001 for the financial support through their grants. The authors would like to thank the members of both panels for participating in the sensorial tests.

ISO, 2005. ISO standard 5495: Sensory analysis: MethodologyPaired comparison test. International Organization for Standardization, Genève.

IVBAM. Vinho Madeira. Instituto do Vinho, do Bordado e do Artesanato da Madeira. February 1, 2017, from http://www.ivbam.gov-madeira.pt/.

Jackson R.S., 2008. Wine science: Principles and applications. 357, 600 p. Academic Press, USA

Jacobson J.L., 2006. Introduction to wine laboratory practices and procedures. 167 p. Springer Science \& Business Media, USA.

Joyeux A., Lafon-Lafourcade S., Ribéreau-Gayon P., 1984. Evolution of acetic acid bacteria during fermentation and storage of wine. Appl. Environ. Microbiol., 48, 153-156.

Lambrechts M.G., Pretorius, I.S., 2000. Yeast and its importance to wine aroma - A review. S. Afr. J. Enol. Vitic, 21, 97-121.

Lima Filho T., Minim V.P., Silva R.C., Della Lucia S.M., Minim L.A., 2015. Methodology for determination of two new sensory thresholds: Compromised acceptance threshold and rejection threshold. Food Res. Int., 76, 561-566.

Nogueira J.M., Nascimento A.M., 1999. Analytical characterization of Madeira wine. J. Agric. Food Chem., 47, 566575 .

OIV 2015. Compendium of International Methods of Analysis of Wines and Musts. International Organisation of Vine and Wine, France.

Pereira V., 2011. Effect of the Estufagem process on the chemical constituents of Madeira wines. PhD Thesis, University of Madeira, Portugal.

Pereira V., Albuquerque F., Cacho J., Marques J.C., 2013. Polyphenols, antioxidant potential and color of fortified wines during accelerated ageing: The Madeira wine case study. Molecules, 18, 2997-3017.

Pereira V., Cacho J., Marques J.C., 2014. Volatile profile of Madeira wines submitted to traditional accelerated ageing. Food Chem., 162, 122-134.

Portaria n³02/2011, de 2 de Dezembro, Diário da República, 2011. Ministério da Agricultura, do Mar, do Ambiente e do Ordenamento do Território. Artigo $3^{\circ}$ - Vinhos licorosos. 
Prescott J., Norris L., Kunst M., Kim S., 2005. Estimating a "consumer rejection threshold" for cork taint in white wine. Food Qual. Prefer., 16, 345-349.

Remize F., Andrieu E., Dequin S., 2000. Engineering of the pyruvate dehydrogenase bypass in Saccharomyces cerevisiae: role of the cytosolic $\mathrm{Mg}(2+)$ and mitochondrial $\mathrm{K}(+)$ acetaldehyde dehydrogenases Ald6p and Ald4p in acetate formation during alcoholic fermentation. Appl. Environ. Microbiol., 66, 3151-3159.

Rudnitskaya A., Rocha S.M., Legin A., Pereira V., Marques J.C., 2010. Evaluation of the feasibility of the electronic tongue as a rapid analytical tool for wine age prediction and quantification of the organic acids and phenolic compounds. The case-study of Madeira wine. Anal. Chim. Acta, 662, 82-89.

Saliba A.J., Bullock J., Hardie W.J., 2009. Consumer rejection threshold for 1,8-cineole (eucalyptol) in Australian red wine. Food Qual.and Prefer, 20, 500-504.
Schaechter M., 2009. Encyclopedia of microbiology. 149 p. Academic Press, USA.

Teixeira M.I., Romão M.V., Bronze M.R., Vilas Boas L., 2006. 2,4,6-Trichloroanisole: A consumer panel evaluation. Cienc. Tec. Vitivinic., 21, 53-65.

Vilela-Moura A., Schuller D., Falco V., Mendes-Faia A., CôrteReal M., 2010. Effect of refermentation conditions and microoxygenation on the reduction of volatile acidity by commercial $S$. cerevisiae strains and their impact on the aromatic profile of wines. Int. J. Food Microbiology, 141, 165-172.

Wildenradt H.L., Singleton V.L., 1974. The production of aldehydes as a result of oxidation of polyphenolic compounds and its relation to wine aging. Am. J. Enol. Vitic, 25, 119-126.

Zoecklein B.W., 2012. Production wine analysis. 98-111 pp.Van Nostrand, USA. 